\title{
Effect of tillage practices on least limiting water range in Northwest India
}

\author{
Meharban S. Kahlon* and Karitika Chawla \\ Department of Soil Science, Punjab Agricultural University, Ludhiana 141004, Punjab, India
}

Received September 13, 2016; accepted April 25, 2017

\begin{abstract}
A b s t r a c t. Tillage practices affect mechanical and hydrological characteristics of soil and subsequently the least limiting water range. This quality indicator under the wheat-maize system of northwest India has not been studied yet. The treatments included four tillage modes, namely conventional tillage, no-tillage without residue, no-tillage with residue, and deep tillage as well as three irrigation regimes based on the irrigation water and pan evaporation ratio i.e. 1.2, 0.9, and 0.6. The experiment was conducted in a split plot design with three replications. At the end of cropping system, the mean least limiting water range $\left(\mathrm{m}^{3} \mathrm{~m}^{-3}\right)$ was found to be highest in deep tillage $(0.26)$ and lowest in notillage without residue $(0.15)$. The field capacity was a limiting factor for the upper range of the least limiting water range beyond soil bulk density $1.41 \mathrm{Mg} \mathrm{m}^{-3}$ and after that $10 \%$ air filled porosity played a major role. However, for the lower range, the permanent wilting point was a critical factor beyond soil bulk density $1.50 \mathrm{Mg} \mathrm{m}^{-3}$ and thereafter, the penetration resistance at $2 \mathrm{MPa}$ becomes a limiting factor. Thus, deep tillage under compaction and no-tillage with residue under water stress is appropriate practice for achieving maximum crop and water productivity.

$\mathrm{K}$ e y w o r d s: least limiting water range, tillage, maize, wheat, soil moisture, crop productivity
\end{abstract}

\section{INTRODUCTION}

Water is considered as a primary factor in limiting crop production. Water deficiency is not only due to rain and its poor distribution but also due to poor structural quality of soil. Many soil physical properties have potential to limit crop production. Plant growth is affected by soil hydro-physical characteristics such as soil water content, aeration, and penetration resistance. A method called nonlimiting water range was first developed (Letey, 1985) to account for each of these limiting soil physical conditions.

*Corresponding author e-mail: dr.mskahlon@rediffmail.com
This concept was later improved and renamed as the least limiting water range (LLWR) by da Silva et al., 1994. The LLWR is defined as the range in soil water within which limitations to plant growth associated with water potential, aeration, and mechanical resistance to root penetration are minimal (da Silva et al., 1994). It integrates the effects of aeration, soil strength, and water potential into one index on the basis of soil water content. The LLWR can be considered to be a useful indicator of soil physical quality for crop production (Asgarzadeh et al., 2010; da Silva and Kay, 2004; Lapen et al., 2004; Leao et al., 2006; Verma and Sharma, 2008). The LLWR is more sensitive to soil structural changes than available water (da Silva et al., 1994; Zou et al., 2000).

The LLWR can be used to evaluate improvement or degradation of soil physical properties. The usefulness of LLWR as an index of soil physical quality in a wide range of soils, crops, and tillage management practices is reported by several researchers (Benjamin et al., 2003; da Silva et al., 1994, 2004; Leao et al., 2006; Wu et al., 2003). Ideal conditions for plant growth are associated with the value of $10 \%$ air porosity (Bowen et al., 1994; Grable and Siemer, 1968) and $2 \mathrm{MPa}$ soil resistance to root development (da Silva et al., 1994). The upper limit is defined at 10\% aeration porosity on volumetric base (Gupta and Allamaras, 1987) or soil water content at field capacity whichever is lower and lower limit is either the soil water content at the permanent wilting point (Savage et al., 1996) or corresponding to $2 \mathrm{MPa}$ (da Silva et al., 1994) soil penetration resistance whichever is higher. When the LLWR is zero, the soil achieves the critical soil bulk density value (Imhoff et

(C) 2017 Institute of Agrophysics, Polish Academy of Sciences 
al., 2001), which indicates that restrictive density affecting root growth and crop yield has been reached (Reichert et al., 2009).

A wide range of LLWR implies that the soil is intermittent to environmental stresses as the plants growing in such soil are less likely to suffer from poor aeration, water stress, and/or mechanical impedance and the soil is more productive, as compared to soil with a narrow range of LLWR (da Silva and Kay, 2004). The LLWR represents a great advance in biophysical studies of soils, and it is considered as the best indicator in relation to plant growth. There are reports showing that soil management systems leading to lower LLWR expose crops to more frequent stress due to excess or lack of water (da Silva and Kay, 1996). Tillage practices may alter soil physical environment by bringing changes in soil mechanical and hydrological changes (Shaver et al., 2002), which subsequently affect the LLWR and crop productivity (Iqbal et al., 2005).

Presently, the rice-wheat system is predominant in northwest India and due to alternate tillage practices in this system, the problems of poor aeration and compaction have started emerging, which may cause soil health and underground water concerns. Studies in Punjab (Kukal and Aggarwal, 2003; and Singh et al., 2009) have shown the presence of a high soil bulk density $\left(\rho_{b}\right)$ layer at $15-25 \mathrm{~cm}$ soil depth under this monoculture. Therefore, there is a need to diversify the prevailing wheat-rice cropping system with the wheat-maize system, which will help in preventing the deterioration of soil health as well as restricting the fall of underground water by consuming less water as compared to rice. So far, the effects of tillage practices on soil mechanical characteristics, LLWR, and crop productivity had not been studied under different tillage and irrigation regimes together in this region. Therefore, the study was planned with the objective to determine the effects of tillage practices on LLWR and to find suitable practice that assures favourable soil environment for achieving higher crop and water productivity.

\section{MATERIALS AND METHODS}

This field experiment was conducted during the growing seasons of 2014 (wheat) and 2015 (maize) at the Research Farm of the Department of Soil Science, Punjab Agricultural University, Ludhiana. The site represents the Indo-Gangetic alluvial plains situated at $30^{\circ} 56^{\prime} \mathrm{N}$ latitude and $75^{\circ} 52^{\prime} \mathrm{E}$ longitude with an altitude of $247 \mathrm{~m}$ above the mean sea level. The area is characterized by a sub-tropical and semi-arid type of climate with hot and dry summer from April to June followed by hot and humid period during July to September and cold winters from November to January. The mean maximum and minimum temperatures show considerable fluctuations during different parts of the year. The summer temperature touches $45^{\circ} \mathrm{C}$ with dry summer spells. Winter experiences frequent frosty spells especially in December and January and minimum temperature dips to $0.5^{\circ} \mathrm{C}$. The experiment comprised four tillage practices, namely conventional tillage (CT), no-tillage without residue (NT), no-tillage with residue (NTR), and deep tillage (DT) in main plots as well as three irrigation regimes based on the irrigation water over pan evaporation ratio i.e. IW/PAN-E ratio of 1.2, 0.9, and 0.6 in subplots for both the crops. However, before wheat crop, the field was under rice-wheat cropping systems with conventional tillage practices. The plots were $4.0 \mathrm{~m}$ wide by $10.0 \mathrm{~m}$ long with treatments replicated three times in a split plot design. In the conventional tillage plots, the field was disked twice followed by two cultivators and one planking operation, while the field in the deep tillage was deep ploughed up to $45 \mathrm{~cm}$ depth with $50 \mathrm{~cm}$ apart and then conventional tillage operations were performed. In no tillage with residue, the sowing of both the crops was made directly under the no-till conditions with retention of crop residue. However, in no-tillage without residue practice, the residues were removed for both the crops and sowing was made under undisturbed soil conditions. The soil was neutral, non-calcareous in nature, and sandy loam in texture (Typic Ustochrept). The sowing of wheat and maize was performed following all recommended packages of practices in the month of October 2014 and May 2015 with a seed rate of 100 and $20 \mathrm{~kg} \mathrm{ha}^{-1}$, respectively. The row-to-row spacing was maintained as $20 \mathrm{~cm}$ in wheat and $60 \mathrm{~cm}$ in maize. The harvesting of wheat and maize were performed in the month of April and October, respectively. The in-situ and laboratory determinations were made for various soil physico-chemical characteristics at the end of the experiment i.e. after maize harvesting.

The in-situ determination of soil bulk density $\left(\rho_{b}\right)$ was made with the help of a cylindrical core having $7.5 \mathrm{~cm}$ height and $8.0 \mathrm{~cm}$ diameter at $0-15$ and $15-30 \mathrm{~cm}$ depths with three replications. The cores were dried in an oven at $105^{\circ} \mathrm{C}$ until the weight of the soil became constant. The ratio of dry soil mass $\left(M_{s}\right)$ and internal volume $\left(V_{t}\right)$ of the cylindrical ring is expressed as bulk density $\left(\rho_{b}\right)$ of soil $\left(\mathrm{Mg} \mathrm{m}^{-3}\right)$ (Blake and Hartge, 1986):

$$
\rho_{b}=\frac{M_{s}}{V_{t}} .
$$

The penetration resistance (PR) of soil was measured with a hand-held digital cone penetrometer (CP40II; Rimik electronics, RFM Australia) at five randomly selected locations within a plot. The soil PR was recorded up to $60 \mathrm{~cm}$ depth. The measurements were made at the end of the wheat-maize cropping cycle along with simultaneous measurements of soil moisture content.

The saturated hydraulic conductivity $\left(K_{s}\right)$ was determined using the constant head method (Reynolds et al., 2002). Undisturbed soil cores $(8 \mathrm{~cm}$ diameter and $7.5 \mathrm{~cm}$ length) were collected from 0-7.5 and 7.5-15 cm depths. Samples were saturated in the laboratory. A saturated soil sample along with the core was connected with another 
core and, to avoid water leakage, grease was applied in the jointing place on the top of a previous core. A thin layer of water was slowly poured on top of the sample by using siphons connected to a constant head device (Mariotte apparatus). The volume of water that percolated through the sample was measured at definite intervals of time. The $K_{s}$ was calculated using the following equation:

$$
K_{s}=\frac{Q}{A t} \frac{L}{H+L},
$$

where: $K_{s}$ - saturated hydraulic conductivity $\left(\mathrm{cm} \mathrm{h}^{-1}\right)$, $Q$ - volume of percolate collected $\left(\mathrm{cm}^{3}\right), L$ - length of soil column (cm), $A-$ cross sectional area of soil column $\left(\mathrm{cm}^{2}\right)$, $t$ - time (h), $H$ - depth of water above soil (cm).

The volumetric soil moisture content in different layers was computed by multiplying the mass water content with the $\rho_{b}$ of a particular layer.

During the growing period of both the crops, the agronomic data on plant height, thousand grain weight, crop biomass, and yield was recorded. The plant height of ten randomly selected plants in each plot was measured with the help of a meter scale from the ground surface to the apex of the plant. A representative sample of one thousand grains for both the crops from each plot was counted manually and weighed on a precision balance and expressed in grams. The crop biomass determination was made by taking all the above ground plant parts of $1 \mathrm{~m}^{2}$ area per plot for both the crops and was dried and weighed. The harvested crop produced from each plot was decobbed separately in the case of maize and thrashed in the case of wheat. The grain yield of both the crops were recorded in $\mathrm{kg}$ from $24 \mathrm{~m}^{2}$ area in each plot and finally expressed in $\mathrm{tha}^{-1}$.

The root distribution was measured at 75 and 95 days after sowing (DAS) in maize and wheat, respectively. The root samples were collected up to $60 \mathrm{~cm}$ depth in both the crops. For root sampling, the soil cores were taken with the help of a core sampler of $5 \mathrm{~cm}$ diameter. Samples were taken in between the plant rows. The root-soil cores were then collected and washed in plastic nets. Roots were carefully separated from the soil by washing the nets under water. The washed roots were further cleaned to remove any leftover weed roots, seed, and other organic debris. The root length density (RLD) $\left(\mathrm{cm} \mathrm{cm}^{-3}\right)$ was calculated from the total length of roots measured by a scanner to the volume of the core.

The water productivity (WP) was calculated by dividing the grain yield of corresponding treatment with the total water use (IW+RF+PWU) $(\mathrm{cm})$ in particular treatment: IW - amount of irrigation water applied (cm), RF - rainfall during crop growth period $(\mathrm{cw}), \mathrm{WU}-$ profile water use $(\mathrm{cw})$.

The data collected on various aspects of the investigations were statistically analysed as prescribed by Cochran and Cox (1967) and adapted by Cheema and Singh (1991) in statistical package CPCS-I. The treatment comparisons were made at a $5 \%$ level of significance.
Soil moisture retention at different matric suctions i.e. $0.03,0.1,0.5,1.0,1.5 \mathrm{MPa}$ was determined with the help of pressure plate apparatus. Brass rings of the core sampler containing undisturbed soil samples were used for determining the soil water content at field capacity, permanent wilting point and other suctions using pressure plate apparatus. Respective matric potential was applied over the undisturbed saturated soil samples in rings until water ceased to flow from the pressure chambers. Then the soil samples were taken out of the chamber and water content was determined gravimetrically. Gravimetric soil water contents at field capacity $(0.03 \mathrm{MPa})$ and permanent wilting point (1.5 MPa) were multiplied with $\rho_{b}$ to give volumetric water content at field capacity and permanent wilting point.

The water content at complete saturation was determined by saturating undisturbed soil samples in rings overnight and then the soil water content of saturated soil was determined gravimetrically, which when multiplied with $\rho_{b}$ gives volumetric water content $\left(\theta_{\text {sat }}\right)$. The volumetric water content at $10 \%$ air filled porosity $\left(\theta_{\mathrm{ap}}\right)$ was determined using a method suggested by da Silva et al. (1994) as follows:

$$
\theta_{a p}=\theta_{\text {sat }}-10 .
$$

Upper limit of LLWR is $10 \%$ aeration porosity on volumetric base $\left(\theta_{a p}\right)$ or soil water content at field capacity (FC) whichever is lower.

Lower limit of LLWR is either soil water content at wilting point or corresponding to $2 \mathrm{MPa}$ soil penetration resistance whichever is higher.

Magnitude of LLWR - soil water content between the upper and lower limit of LLWR.

\section{RESULTS}

The soil bulk density $\left(\rho_{b}\right)$, a prominent factor in qualifying the compaction state of soil, was found to be significantly affected by tillage practices both at the surface 0-15 $\mathrm{cm})$ and sub-surface soil layers $(15-30 \mathrm{~cm})$. In deep tillage with deep ploughing of field up to $45 \mathrm{~cm}$ depth, the soil $\rho_{b}$ decreased up to $8 \%$ as compared to NT in the subsurface soil layer (Table 1). This demonstrates the effectiveness of chiselling as a mechanical practice to minimize the limiting factors to the development and productivity of plants. The decrease in soil $\rho_{b}$ with intensive tillage practices was also reported by Diaz-Zorita (2004); Khurshid et al. (2006) and Ji et al. (2013). Maximum soil $\rho_{b}$ (1.57 and $1.76 \mathrm{Mg} \mathrm{m}^{-3}$ ) was recorded in no-tillage without residue practice at $0-15$ and $15-30 \mathrm{~cm}$ soil depths, respectively. Likewise soil $\rho_{b}$, the PR (MPa) was found to be significantly affected by tillage practices at lower soil depths (Table 1). Due to shattering of soil up to $45 \mathrm{~cm}$ depth and $50 \mathrm{~cm}$ apart, the soil was loosened from the lateral and vertical downward direction. This helped in achieving minimum PR under deep tillage. At the surface soil layer 
T a b l e 1. Soil bulk density, saturated hydraulic conductivity and penetration resistance under different tillage practices in wheatmaize cropping system

\begin{tabular}{|c|c|c|c|c|c|c|}
\hline \multirow{2}{*}{$\begin{array}{l}\text { Tillage } \\
\text { practices }\end{array}$} & \multicolumn{2}{|c|}{$\begin{array}{l}\text { Bulk density } \\
\left(\mathrm{Mg} \mathrm{m}^{-3}\right)\end{array}$} & \multicolumn{2}{|c|}{$\begin{array}{l}\text { Saturated hydraulic conductivity } \\
\qquad\left(\mathrm{cm} \mathrm{h}^{-1}\right)\end{array}$} & \multicolumn{2}{|c|}{$\begin{array}{l}\text { Penetration resistance } \\
(\mathrm{MPa})\end{array}$} \\
\hline & $0-15$ & $15-30$ & $0-15$ & $15-30$ & $0-15$ & $15-30$ \\
\hline $\mathrm{CT}$ & 1.49 & 1.70 & 3.92 & 2.81 & 0.59 & 2.45 \\
\hline NT & 1.57 & 1.76 & 4.46 & 3.41 & 0.57 & 2.23 \\
\hline NTR & 1.53 & 1.74 & 5.11 & 4.33 & 0.55 & 2.30 \\
\hline DT & 1.47 & 1.63 & 5.36 & 4.63 & 0.46 & 1.60 \\
\hline Mean & 1.51 & 1.70 & 4.71 & 3.79 & 0.54 & 2.15 \\
\hline $\operatorname{LSD}(<0.05)$ & 0.07 & 0.05 & 1.01 & 0.95 & NS & 0.36 \\
\hline
\end{tabular}

CT - conventional tillage, NT - no-tillage without residue, NTR - no-tillage with residue, DT - deep tillage.

$(0-15 \mathrm{~cm})$, the PR was maximum under conventional tillage $(0.59)$ followed by no-tillage without residue $(0.57)$, no-tillage with residue (0.55), and least under deep tillage (0.46). Thus, there was no significant difference at the surface layer under different tillage practices. However, at the subsurface layer $(15-30 \mathrm{~cm})$, the PR was found to be significantly increased up to $2.45,2.23$, and 2.30 in conventional tillage, in no-tillage without residue, and in no-tillage with residue, respectively. In turn, in the case of deep tillage, the increase in PR was only up to 1. $60 \mathrm{MPa}$. The high PR in conventional tillage may be due to hard pan formation caused by the use of heavy machinery for performing five field operations before actual sowing of the crop. However, deep tillage caused physical manipulation of subsurface soil and increased soil porosity leading to a decrease in PR. A similar trend was observed for other soil layers (Fig. 1a). The data pertaining to the effect of tillage practices on saturated hydraulic conductivity $\left(K_{s}\right)$ is presented in Table 1. Maximum $K_{s}\left(\mathrm{~cm} \mathrm{~h}^{-1}\right)$ was observed in deep tillage (5.36 and 4.63), followed by no-tillage with residue (5.11 and 4.33), no-tillage without residue (4.46 and 3.41), and conventional tillage (3.92 and 2.81) at 0-15 and $15-30 \mathrm{~cm}$ depths, respectively. The removal of the hard layer at the subsurface level through chiselling enhanced more open and more homogeneous water movement through the soil. However, continuous conventional tillage caused a decrease in soil organic matter content, which was associated to a decrease in aggregate stability, consequently leading to the formation of surface crusts. Surface crusts are a dangerous aspect of soil degradation; they are formed mainly by raindrop impact, which causes the mechanical
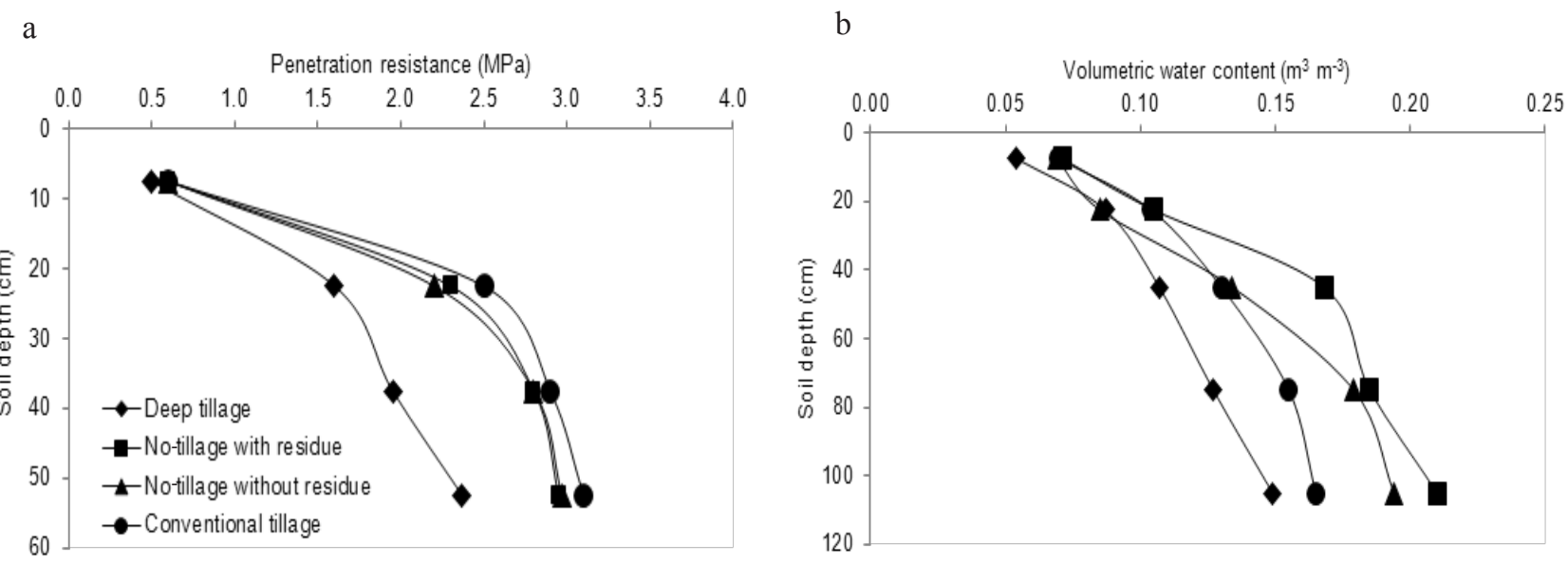

Fig. 1. Penetration resistance (a) and volumetric soil water content (b) under different tillage practices. 
destruction of soil aggregates, thus reducing seedling emergence, soil-atmosphere gas exchange, water infiltration, and $K_{s}$. The data on the effect of tillage practices on the volumetric soil moisture content $(\theta)$ at different soil depths is presented in Fig. 1b. Mean maximum $\theta$ was observed in no-tillage with residue, followed by no-tillage without residue, conventional tillage, and deep tillage. As the soil disturbance increased by frequent tillage practices, the $\theta$ decreased. However, with an increase in soil depth, the $\theta$ also increased. The data on soil moisture characteristics is presented in Fig. 2a.

The effect of tillage practices on RLD of maize and wheat is presented in Table 2. At the surface layer $(0-15 \mathrm{~cm})$, the RLD $\left(\mathrm{cm} \mathrm{cm}^{-3}\right)$ was found to be maximum under deep tillage (1.78), followed by conventional tillage (1.13), notillage with residue (1.07), and no-tillage without residue (0.85). High RLD was observed in deep tillage attributed

\section{a}

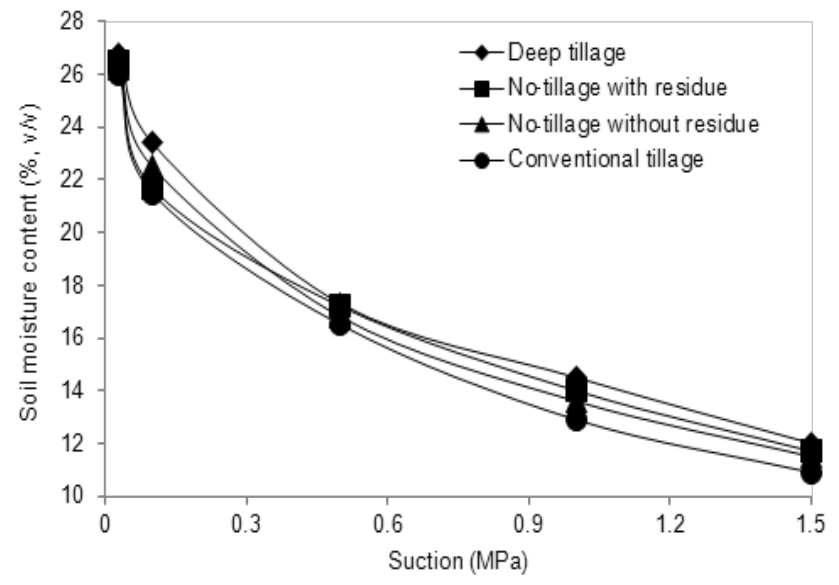

to loosening of soil, which helps in greater root proliferation. The RLD of wheat varied significantly among the tillage practices. Maximum mean RLD $\left(\mathrm{cm} \mathrm{cm}^{-3}\right)$ at $0-15 \mathrm{~cm}$ depth was observed in deep tillage (1.25) and the least in no-tillage without residue (0.83). At 15-60 $\mathrm{cm}$ depth, RLD $\left(\mathrm{cm} \mathrm{cm}^{-3}\right)$ was in the range of $0.33-0.66$ in conventional tillage, $0.21-0.44$ in no-tillage without residue, $0.27-0.57$ in no-tillage with residue, and 0.36 0.72 in deep tillage. The data pertaining to the effect of tillage practices on plant height $(\mathrm{m})$ is presented in Table 3. Tillage practices significantly affect the plant height of both the crops. Mean maximum plant height $(\mathrm{cm})$ of wheat was observed in deep tillage (1.05) followed by no-tillage without residue (1.02), conventional tillage (1.01), and notillage with residue (0.98). However, in maize the trend of plant height among the tillage practices was of the order deep tillage $>$ no-tillage with residue $>$ no-tillage without residue $>$ conventional tillage. The thousand grain weight

b

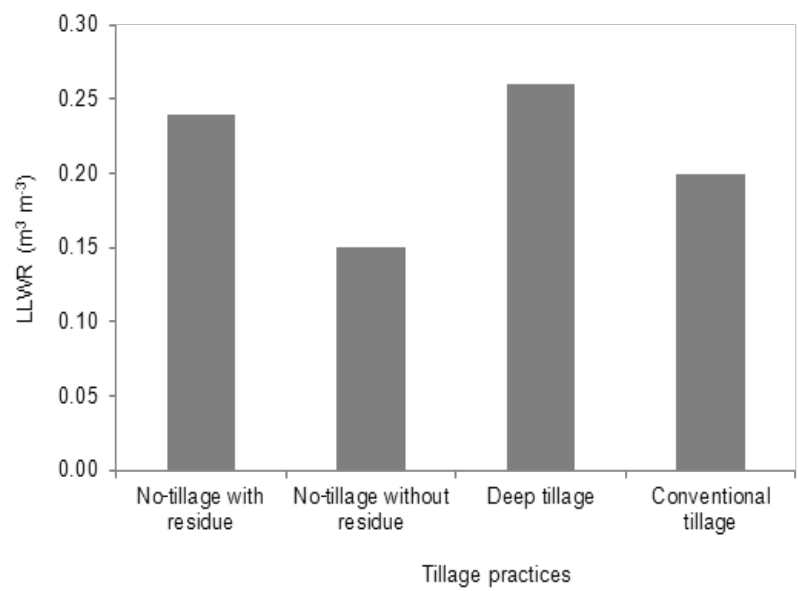

Fig. 2. Soil moisture content at different suction (a) and mean least limiting water range (LLWR) (b) under different tillage practices.

T a b I e 2. Root length density $\left(\mathrm{cm} \mathrm{cm}^{-3}\right)$ under different tillage practices in wheat-maize cropping system at different soil depths

\begin{tabular}{|c|c|c|c|c|c|c|c|c|}
\hline \multirow{3}{*}{$\begin{array}{c}\text { Tillage } \\
\text { practices }\end{array}$} & \multicolumn{4}{|c|}{ Wheat } & \multicolumn{4}{|c|}{ Maize } \\
\hline & \multicolumn{8}{|c|}{ Soil depth $(\mathrm{cm})$} \\
\hline & $0-15$ & $15-30$ & $30-45$ & $45-60$ & $0-15$ & $15-30$ & $30-45$ & $45-60$ \\
\hline $\mathrm{CT}$ & 0.95 & 0.66 & 0.48 & 0.33 & 1.13 & 0.87 & 0.63 & 0.48 \\
\hline NT & 0.83 & 0.44 & 0.31 & 0.21 & 0.85 & 0.59 & 0.47 & 0.37 \\
\hline NTR & 1.04 & 0.57 & 0.39 & 0.27 & 1.07 & 0.86 & 0.55 & 0.44 \\
\hline DT & 1.25 & 0.72 & 0.48 & 0.36 & 1.78 & 1.22 & 0.76 & 0.57 \\
\hline Mean & 1.02 & 0.60 & 0.42 & 0.29 & 1.21 & 0.89 & 0.60 & 0.46 \\
\hline $\operatorname{LSD}(<0.05)$ & 0.13 & 0.08 & 0.07 & 0.07 & 0.38 & 0.21 & 0.16 & 0.09 \\
\hline
\end{tabular}

Explanations as in Table 1. 
(TGW) (g), a major yield contributing factor, was observed to be maximum under deep tillage (45.7 and 305.7) for wheat and maize, respectively. Minimum TGW was observed in no-tillage without residue in wheat and conventional tillage in maize. Significantly higher water productivity was observed under deep tillage in both the crops; however, the lowest water productivity was observed under no-tillage without residue in wheat and under conventional tillage in maize (Table 3). Among various irrigation regimes, the mean maximum plant height was observed in IW/PAN-E 1.2 (I1) in wheat and IW/PAN-E 0.9 (I2) in maize (Table 4). Maximum TGW, crop biomass, crop yield, and water productivity was observed at the I1 regime in wheat but in maize maximum TGW and yield was observed at the IW/ PAN-E 0.9 (I2) regime. The maximum water productivity was observed at the IW/PAN-E 0.6 (I3) regime in maize.

The data related to the effect of different tillage practices on mean LLWR is presented in Fig. 2b. The mean LLWR $\left(\mathrm{m}^{3} \mathrm{~m}^{-3}\right)$ was found to be highest in deep tillage $(0.26)$ followed by no-tillage with residue $(0.24)$, conventional tillage (0.20) and no-tillage without residue (0.15). With an increase in tillage intensity, the LLWR also increases. The variation in soil $\rho_{b}$ under different tillage practices results in different soil water content values. The data on volumetric water content of soil in relation to soil $\rho_{b}$ is presented in Fig. 3. Among different tillage practices, the field capacity was the limiting factor for the upper range of LLWR beyond $\rho_{b}\left(\mathrm{Mg} \mathrm{m}^{-3}\right) 1.41$, after that $10 \%$ air filled porosity (AFP) became the limiting factor. For the lower range, the PWP was the limiting factor beyond $\rho_{b}\left(\mathrm{Mg} \mathrm{m}^{-3}\right) 1.50$ and thereafter PR $2 \mathrm{MPa}$ became the limiting factor for different tillage practices. In the case of conventional tillage for the upper value of LLWR, FC was the limiting factor up to $\rho_{b}$ $1.37 \mathrm{Mg} \mathrm{m}^{-3}$, after that $10 \%$ AFP became the limiting factor and for lower PWP was limiting up to $\rho_{b} 1.44 \mathrm{Mg} \mathrm{m}^{-3}$, then PR $2 \mathrm{MPa}$ was limiting. In no-tillage with residue for the upper value, FC was the limiting factor up to $\rho_{b}$ $1.41 \mathrm{Mg} \mathrm{m}^{-3}$ and thereafter $10 \% \mathrm{AFP}$ was the limiting factor. For the lower value, permanent wilting point (PWP) was limiting up to $\rho_{b} 1.54 \mathrm{Mg} \mathrm{m}^{-3}$, after that PR $2 \mathrm{MPa}$ was limiting. In the case of DT, the upper value of LLWR was FC up to $\rho_{b}$ $1.40 \mathrm{Mg} \mathrm{m}^{-3}$, after that $10 \%$ AFP was limiting. For the lower

T a b I e 3. Plant height, thousand grain weight, crop biomass, crop yield and water productivity of wheat and maize under different tillage practices

\begin{tabular}{|c|c|c|c|c|c|c|c|c|c|c|}
\hline \multirow{2}{*}{$\begin{array}{c}\text { Tillage } \\
\text { practices }\end{array}$} & \multicolumn{2}{|c|}{$\begin{array}{l}\text { Plant height } \\
(\mathrm{cm})\end{array}$} & \multicolumn{2}{|c|}{$\begin{array}{c}\text { Thousand grain } \\
\text { weight }(\mathrm{g})\end{array}$} & \multicolumn{2}{|c|}{$\begin{array}{l}\text { Crop biomass } \\
\left(\mathrm{Mg} \mathrm{ha}^{-1}\right)\end{array}$} & \multicolumn{2}{|c|}{$\begin{array}{l}\text { Crop yield } \\
\left(\mathrm{Mg} \mathrm{ha}^{-1}\right)\end{array}$} & \multicolumn{2}{|c|}{$\begin{array}{l}\text { Water productivity } \\
\left(\mathrm{Mg} \mathrm{ha}^{-1} \mathrm{~mm}^{-1}\right)\end{array}$} \\
\hline & wheat & maize & wheat & maize & wheat & maize & wheat & maize & wheat & maize \\
\hline CT & 1.01 & 2.42 & 42.7 & 283.9 & 13.6 & 15.5 & 4.27 & 5.96 & 26.4 & 7.76 \\
\hline NT & 1.02 & 2.66 & 39.8 & 296.8 & 13.9 & 15.9 & 4.08 & 5.92 & 25.1 & 8.30 \\
\hline NTR & 0.98 & 2.69 & 40.7 & 294.8 & 14.5 & 16.9 & 4.13 & 6.54 & 25.7 & 9.84 \\
\hline DT & 1.05 & 2.74 & 45.7 & 305.7 & 15.4 & 18.1 & 4.46 & 6.92 & 27.2 & 10.21 \\
\hline Mean & 1.01 & 2.63 & 42.2 & 295.3 & 14.4 & 16.6 & 4.23 & 6.34 & 26.1 & 9.03 \\
\hline LSD $(<0.05)$ & 0.04 & 0.12 & 1.52 & 10.9 & 1.06 & 1.24 & 0.17 & 0.31 & 0.74 & 0.83 \\
\hline
\end{tabular}

Explanations as in Table 1.

T a b l e 4. Plant height, thousand grain weight, crop biomass, crop yield and water productivity of wheat and maize under different irrigation regimes

\begin{tabular}{cccccccccccc}
\hline \multirow{2}{*}{$\begin{array}{c}\text { Irrigation } \\
\text { regimes }\end{array}$} & \multicolumn{2}{c}{ Plant height $(\mathrm{cm})$} & \multicolumn{2}{c}{$\begin{array}{c}\text { Thousand grain } \\
\text { weight }(\mathrm{g})\end{array}$} & $\begin{array}{c}\text { Crop biomass } \\
\left(\mathrm{Mg} \mathrm{ha}^{-1}\right)\end{array}$ & $\begin{array}{c}\text { Crop yield } \\
\left(\mathrm{Mg} \mathrm{ha}^{-1}\right)\end{array}$ & $\begin{array}{c}\text { Water productivity } \\
\left(\mathrm{Mg} \mathrm{ha}^{-1} \mathrm{~mm}^{-1}\right)\end{array}$ \\
\cline { 2 - 10 } mheat & maize & wheat & maize & wheat & maize & wheat & maize & wheat & maize \\
\hline I1 & 1.028 & 2.65 & 44.2 & 293.1 & 15.2 & 17.1 & 4.60 & 6.22 & 27.3 & 8.58 \\
I2 & 1.007 & 2.68 & 41.8 & 301.1 & 14.2 & 16.5 & 4.15 & 6.63 & 26.0 & 8.97 \\
I3 & 1.002 & 2.56 & 40.5 & 291.7 & 13.9 & 16.1 & 3.95 & 6.15 & 25.1 & 9.54 \\
Mean & 1.012 & 2.63 & 42.2 & 295.3 & 14.4 & 16.6 & 4.23 & 6.33 & 26.1 & 9.03 \\
LSD $(<0.05)$ & 0.016 & NS & 1.80 & 7.90 & 0.70 & 0.60 & 0.34 & 0.31 & 1.20 & 0.56 \\
\hline
\end{tabular}

$\mathrm{I} 1$ - IW/ PAN-E ratio 1.2; I2 - IW/ PAN-E ratio 0.9; I3 - IW/ PAN-E ratio 0.6 (both in maize and wheat). 

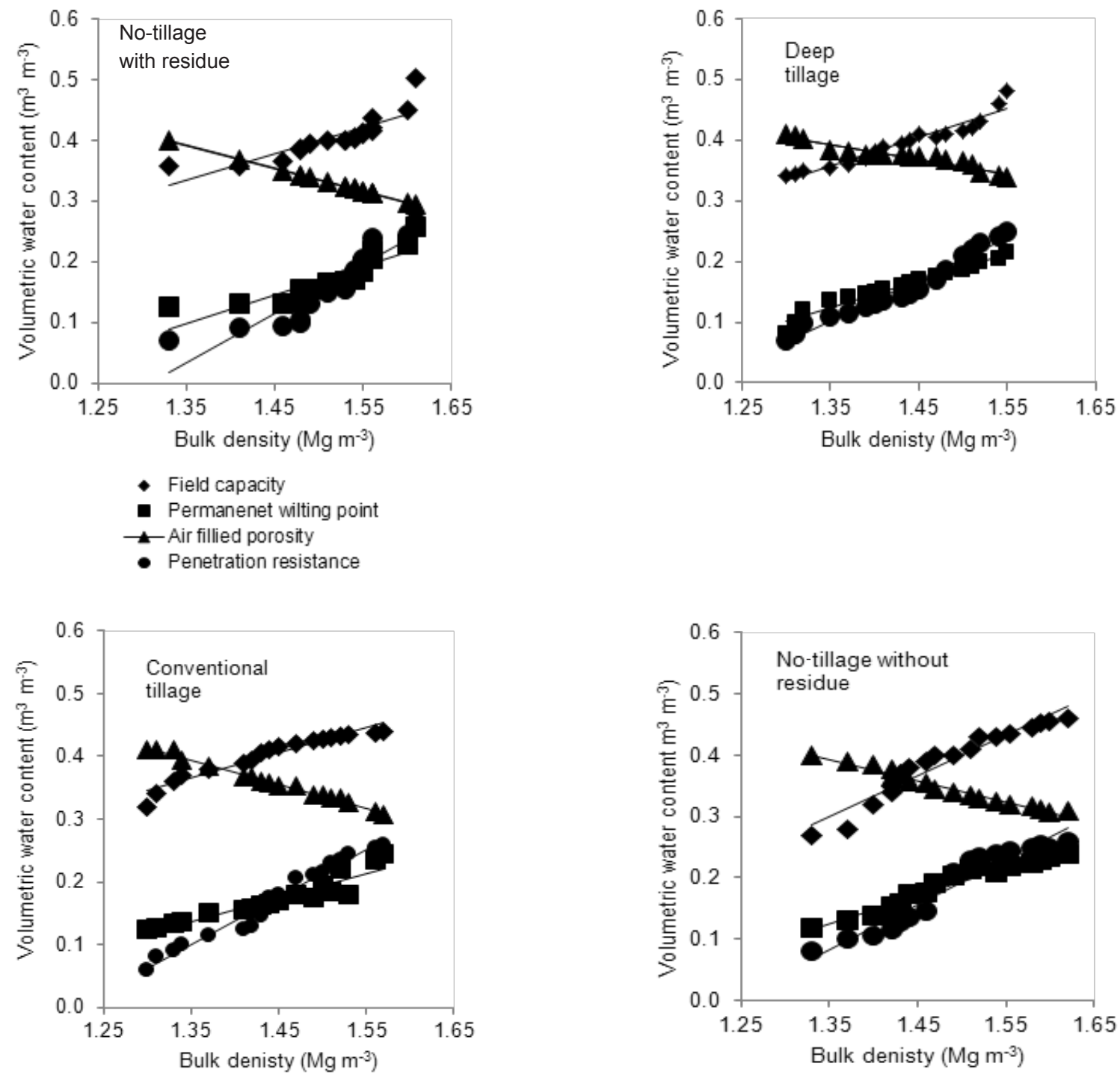

Fig. 3. Volumetric soil water content in relation to bulk densities under different tillage practices.

value, PWP was limiting up to $\rho_{b} 1.45 \mathrm{Mg} \mathrm{m}^{-3}$, then $2 \mathrm{MPa}$ $\mathrm{PR}$ became limiting. In the case of no-tillage without residue, the FC was the limiting factor up to $\rho_{b}\left(1.45 \mathrm{Mg} \mathrm{m}^{-3}\right)$; thereafter $10 \%$ AFP became limiting. For the lower value, the PWP was the limiting factor up to $\rho_{b} 1.52 \mathrm{Mg} \mathrm{m}^{-3}$, after that $2 \mathrm{MPa}$ was limiting. LLWR had a maximum value in deep tillage followed by conventional tillage, no-tillage with residue, and the least value under no-tillage without residue.

The soil bulk density and PR represent the compaction conditions of soil and have a significant effect on crop physiology. The relation between $\mathrm{PR}$ and $\rho_{b}$ and grain yield is presented in Fig. $4 \mathrm{a}$ and $\mathrm{b}$. There is a positive relation between PR and $\rho_{b}$. However, the relation between PR and grain yield was found to be negative, as presented in Fig. 4b. The fact of considering LLWR as a good indicator of crop productivity was found to be correct in the present study with a correlation coefficient of 0.85 in maize and 0.90 in wheat (Fig. 5). Different tillage practices alter pore size distribution, increase microporosity, and thus affect soil $\rho_{b}$. Figure 6 presents the relation between $\rho_{b}$ and LLWR. There is a negative relation between $\rho_{b}$ and LLWR. The increase in $\rho_{b}$ decreases the LLWR in all tillage systems. In relation to LLWR, the increase in $\rho_{b}$ increases soil $\mathrm{PR}$, decrease the soil water content at FC, and reduces aeration. At the same $\rho_{b}$, LLWR was found to be in the order deep tillage $>$ no-tillage with residue $>$ conventional tillage $>$ no-tillage without residue. The $\theta$ increases with an increase in $\rho_{b}$ due to the reduction in macroporosity, which leads to narrow LLWR.

\section{DISCUSSION}

Mean maximum volumetric water content after a complete wheat-maize cropping cycle was observed under no-tillage with residue, followed by no-tillage without residue, conventional tillage, and deep tillage. The no-tillage with residue practice conserved more moisture probably 
a

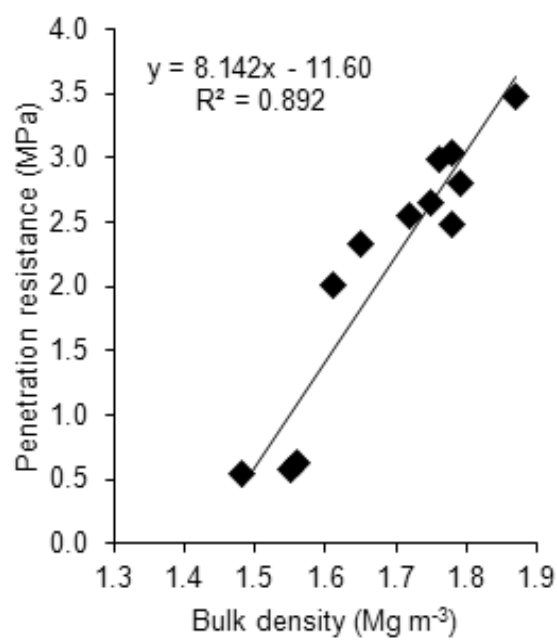

b

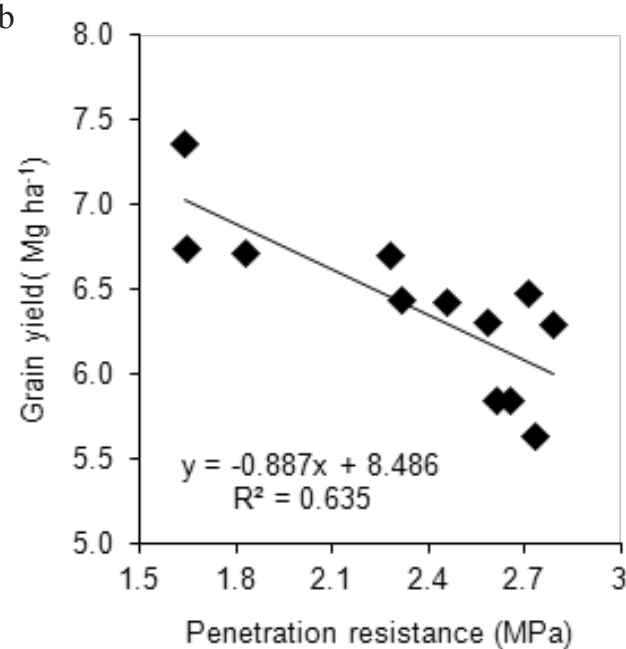

Fig. 4. Relationship between bulk density and penetration resistance (a) and maize grain yield and penetration resistance (b).

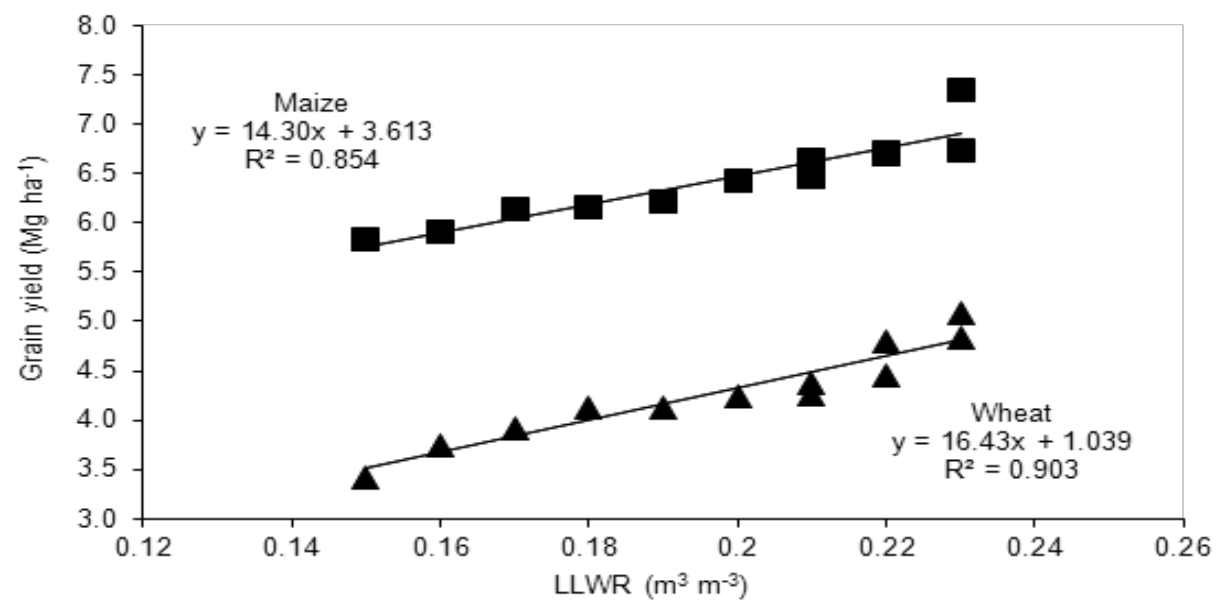

Fig. 5. Relationship between least limiting water range (LLWR) and grain yield of wheat and maize.

because of the retention of crop residues on the soil surface, interception of rainfall, reduction of runoff, evaporation, and an increase in available water capacity as compared to other tillage practices where the crop residue was completely removed. Similar observations were also reported by Filho et al. (2013); Kebede and Bekelle (2008); Rashidi and Keshavarzpour (2007); and Wang et al. (2009). Further, the tillage-induced disturbance and the pulverizing effect under conventional tillage and deep tillage produce a finer and loose soil structure, which has fewer retention pores than in no-tillage with residue. Soil disturbance and tillage frequency decreases volumetric water content (Hussain et al., 1998). As in this study, the increase in soil moisture with depth was also reported by Dao (1993); Kahlon et al. (2012); Kebede and Bekelle (2008).

The deep tillage promotes higher root proliferation because of loosened soil conditions both laterally and vertically downward performed by deep ploughing the field.
Zhao et al. (2014) also reported that RLD of deep tillage at $0-10,10-20,20-30$, and 30-40 cm depths were higher than conventional tillage by $28.7,50.0,52.5$, and $64.0 \%$, respectively. Ji et al. (2013) and Wang et al. (2009) also reported higher RLD under deep tillage than conventional tillage. However, soil compaction, particularly of the deeper soil layers, may have caused a significant decrease of RLD with depth. The highest plant height, TGW, biomass and crop productivity of both the crops observed under deep tillage are attributed to enhanced nutrients and moisture availability than other tillage practices. Liu et al. (2010) concluded that maize with mulch improved the ecological environment of the soil, increased soil temperature and soil water contents, promoted the growth of maize, and increased crop yield.

The increase in $\rho_{b}$ increased the cohesion of the soil particles, decreased macroporosity, reduced soil aeration, and increased the risk of soil compaction, which led to 

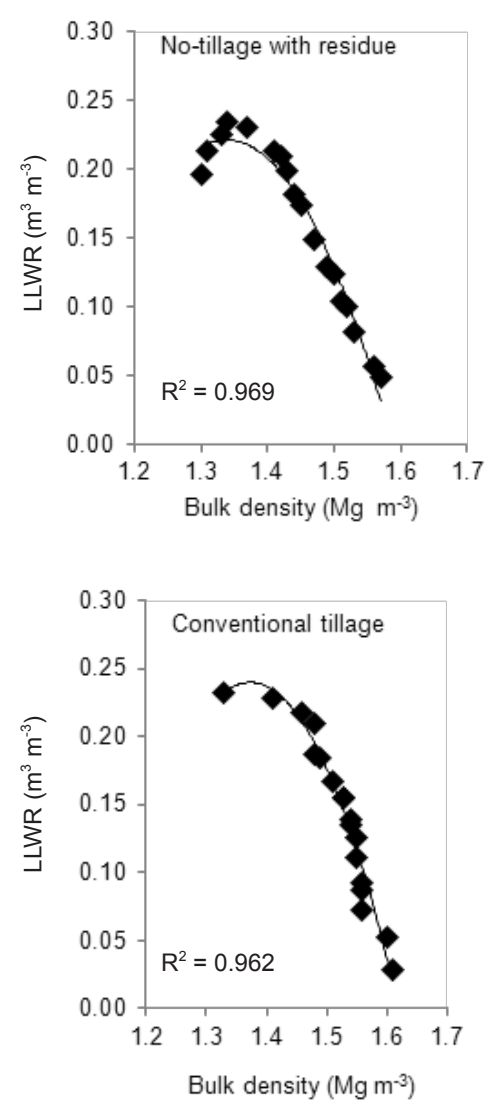
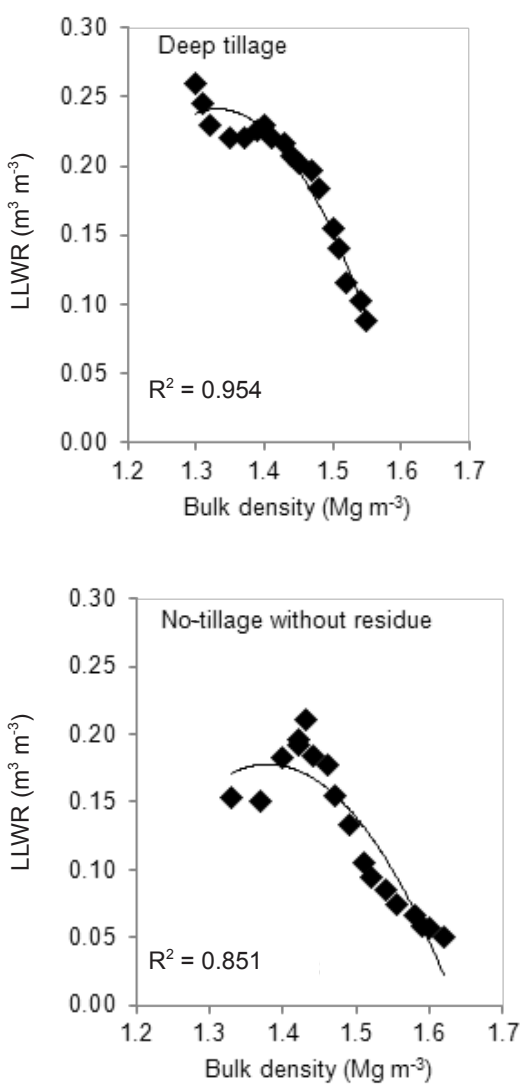

Fig. 6. Least limiting water range (LLWR) in relation to soil bulk density under different tillage practices.

decreased water content at AFP and increased PR within the LLWR. Chiselling decreased soil $\rho_{b}$ and increased the LLWR magnitude by lowering the soil water content at which PR reaches 2.0 MPa. Similar observations were also recorded by Calonego et al. (2011). Higher LLWR in soil under chiselling, results in a favourable physical environment for root growth (Betz et al., 1998; Cavalieri et al., 2006). Kadziene et al. (2011) also found a greater LLWR for ploughed and harrowed systems than for notillage without residue. The effect of bio-pores on PR was greater in no-tillage without residue because of undisturbed compaction conditions, which decreased LLWR. This may also be because of the higher $\rho_{b}$ found in the conservation system where soil resistance reaches $2.0 \mathrm{MPa}$ at higher moisture contents. These results are in accordance with that of Kaufmann et al. (2010) and Olibone et al. (2010). In the $0-15 \mathrm{~cm}$ soil layer, zero tillage with residue $(\mathrm{ZT}+\mathrm{R})$, permanent broad bed with residue $(\mathrm{PBB}+\mathrm{R})$, and permanent narrow-beds with residue $(\mathrm{PNB}+\mathrm{R})$ had nearly 13,24 , and $11 \%$ higher mean LLWR values than ZT, PBB, and PNB plots, respectively; the crop residue retention improved LLWR (Mishra et al., 2015). Mean LLWR was $40 \%$ greater in conventional tillage than in notillage without residue (Filho et al., 2013).
With an increase in LLWR $\left(\mathrm{m}^{3} \mathrm{~m}^{-3}\right)$, the grain yield $\left(\mathrm{Mg} \mathrm{ha}^{-1}\right)$ increased, as it provides more availability of moisture for plants to utilize and offers less restriction for roots. It provides a better environment for plants to grow. The grain yield increases due to a decrease in soil PR associated with non-limiting conditions water and nutrient availability. According to Kay et al. (2006), the LLWR of a soil can be directly linked to physiological limitations of plant growth. A significant and positive correlation was also observed between LLWR and wheat grain yield by Sharma and Bhushan (2001). There was a negative relation between $\rho_{b}$ and LLWR. Among tillage practices, the LLWR was of the order deep tillage $>$ no-tillage with residue $>$ conventional tillage $>$ no-tillage without residue. The $\theta$ increases with an increase in $\rho_{b}$ due to the reduction in macroporosity, leading to narrow LLWR. A decrease in LLWR with an increase in soil $\rho_{b}$ was also reported by Choudhary et al. (2008); da Silva and Kay (1997); Kauffman et al. (2010); and Calonego et al. (2011). The increase in soil $\rho_{b}$ under deep tillage $>$ no-tillage with residue $>$ conventional tillage $>$ no-tillage with residue due to undisturbed soil surface leading to soil compaction was also reported by Ram et al. (2010), and Alvarez and Steinbach (2009). The soil $\rho_{b}$ and PR were significantly lower in plots with tillage due to reduction in compaction and an increase in porosity. In 
deep tillage, due to the loosening of soil to the deeper layer, the PR was found to be minimal as compared to other tillage practices, and grain yield was maximal due to availability of water and nutrients from deeper layers. As the PR decreases, soil helps in maintaining effective plant rooting and facilitates good water and nutrient uptake by plants, which subsequently help in improving the crop yield. The PR measurements of soil can be used to assess the need for tillage operations, which help maintain effective plant rooting and facilitate good water and nutrient uptake. Soil PR was negatively correlated with soil water content and positively correlated with $\rho_{b}$ (Filho et al., 2013). With an increase in LLWR $\left(\mathrm{m}^{3} \mathrm{~m}^{-3}\right)$, the grain yield $\left(\mathrm{t} \mathrm{ha}^{-1}\right)$ increases as it provides more moisture for plants to utilize and offers less restriction for roots. It provides a better environment for plants to grow. With an increase in LLWR, the limiting condition associated with soil PR decreases leading to an increase in water and nutrient availability, thus grain yield increases. The LLWR of a soil can be directly linked to physiological limitations of plant growth (Kay et al., 2006). Memon et al. (2013) also reported that maize had the greatest plant height under deep tillage than conventional tillage because of enhanced nutrients and moisture availability in deep tillage than conventional tillage.

There was a significant change in the soil $\rho_{b}$ and PR in deep tillage due to shattering and loosening of soil up to $45 \mathrm{~cm}$ depth and $50 \mathrm{~cm}$ apart. This reduced compaction under deep tillage provides a better soil environment for achieving a wider LLWR. The compaction changes the pore size distribution of the bulk soil with an increase in micro porosity and a decrease in macro porosity. This is also reflected by an increase in soil bulk density. The changes in soil structure due to compaction have three consequences related to LLWR: an increase in soil PR, a decline in soil water content at FC, and a reduction of air at high water content. The compaction recorded in no-tillage without residue due to undisturbed soil conditions decreased the LLWR as was also reported by da Silva and Kay (1997) and Tormena et al. (1999). Among tillage practices, the $\Theta_{\text {AFP }}$ was the upper limit of LLWR when the bulk density was greater than $1.40 \mathrm{Mg} \mathrm{m}^{-3}$.

\section{CONCLUSIONS}

1. The deep tillage helped in reducing the soil compaction by lowering soil bulk density and penetration resistance and thus, provided better environment for root proliferation as well as water and nutrient uptake from the deeper soil layers.

2. The least limiting water range was found to be a good soil quality indicator, particularly in northwest India, where soil compaction at the subsurface soil layer $(15-30 \mathrm{~cm})$ is an emerging problem due to alternate tillage practices in a monoculture system. The mean highest least limiting water range was observed in deep tillage and the lowest in no-tillage without residue. The least limiting water range decreases with increases in soil bulk density.

3 . The irrigation regimes did not significantly influence the mechanical and hydrological properties of the soil, thus the least limiting water range was unaffected by these regimes. However, the irrigation regimes significantly influence the plant parameters and productivity of both wheat and maize.

4. With the increase in the least limiting water range, the grain yield increased which was attributed to better soil environment for root proliferation and crop growth. Thus, under compaction (hard pan formation), the deep tillage is the best practice to opt for achieving maximum crop and water productivity, whereas the no-tillage with residue practice is a viable option under water stress conditions.

Conflict of interest: The Authors do not declare conflict of interest.

\section{REFERENCES}

Alvarez R. and Steinbach H.S., 2009. A review of the effect of tillage system on some soil physical properties, water content, nitrate availability and crops yield in the Argentine Pampus. Soil Till. Res., 104, 1-15.

Asgarzadeh H., Mosaddeghi M.R., Mahboubi A.A., Nosrati A., and Dexter A.R., 2010. Soil water availability for plants as quantified by conventional available water, least limiting water range and integral water capacity. Pl. Soil, 335, 229-44.

Benjamin J.G., Nielsen D.C., and Vigil M., 2003. Quantifying effects of soil conditions on plant growth and crop production. Geoderma, 161, 137-148.

Betz C.L., Allmaras R.R., Copeland S.M., and Randall G.W., 1998. Least limiting water range: Traffic and long-term tillage influences in a Webster soil. Soil. Sci. Soc. Am. J., 62, 1384-1393.

Blake G.R. and Hartge K.H., 1986. Bulk density. In: Methods of Soil Analysis. Part 1. (Ed. A. Klute) Agron. Monogr. 9. ASA and SSSA, Madison, WI, USA..

Bowen H.D., Garner T.H., and Vaughn D.H., 1994. Advances in soil-plant dynamics. In: Advances in Soil Dynamics, ASAE, St. Joseph, 255-280.

Calonego J.C. and Rosolem C.A., 2011. Least limiting water range in soil under crop rotation and chiseling. $\mathrm{R}$. Bras. $\mathrm{Ci}$ Solo., 35, 759-771.

Cavalieri K.M.V., Tormena C.A., Filho P.S.V., Gonclave A.C.A., and Costa A.C.A., 2006. Effect of tillage system on the soil physical properties of a dystrophic red latosol. R. Bras. Ci. Solo., 30, 137-147.

Cheema H.S. and Singh B., 1991. Software statistical package CPCS-1. Department of Statistics, PAU, Ludhiana.

Choudhary K.K., Aggarwal P., and Singh K., 2008. Variation of least limiting water range with compaction for divergent textured soils. J. Ind. Soc. Soil. Sci., 56, 260-266.

Cochran W.G. and Cox G.M., 1967. Experimental designs. Wiley Press, New York, USA. 
da Silva A.P. and Kay B.D., 1994. Characterization of the least limiting water range of soils. Soil Sci. Soc. Am. J., 58, 1775-1781.

da Silva A.P. and Kay B.D., 1996. The sensitivity of shoot growth of corn to the least limiting water range of soils. Plant Soil., 184, 323-329.

da Silva A.P. and Kay B.D., 1997. Estimating the least limited water range of soils from properties and management . Soil Sci. Soc. Am. J., 61, 877-883.

da Silva A.P. and Kay B.D., 2004. Linking process capability analysis and least limiting water range of assesing soil physical quality. Soil Till. Res., 79, 167-174.

da Silva A.P., Kay B.D., and Perfect E., 1994. Characterization of the least limiting water range of soils. Soil Sci. Soc. Am. J. 58, 1775-1781.

Dao T.H., 1993. Tillage and winter wheat residue management effects on water infiltration and storage. Soil Sci. Soc. Am., J., 57, 1586-1595.

Diaz-Zorita M., Grove J.H., Murdock L., Herbeck J., and Perfect E., 2004 Soil structural disturbance effects on crop yields and soil properties in a no-till production system. Agron. J., 96, 1651-1659.

Filho O.G., Blanco-Canqui H., and Silva A.P., 2013. Least limiting water range of the soil seedbed for long-term tillage and cropping systems in the central great plains. USA. Geoderma, 208, 99-110.

Grable A.R. and Siemer E.G., 1968. Effects of bulk density, aggregate size, and soil water suction on oxygen diffusion, redox potential and elongation of corns roots. Soil Sci. Soc. Am. J., 32,180-186.

Gupta S.C. and Allmaras R.R., 1987. Models to assess the suitability of soils to excessive compaction. Adv. Soil. Sci., 6, 65-100.

Hussain I., Olson K.R., and Siemens L.C., 1998. Long-term tillage effects on physical properties of eroded soil. Soil Sci., 163, 970-981.

Imhoff S., Silva A.P., Junior M., and Tormena C.A., 2001. Quantifying critical pressures for plant growth. J. Soil. Sci., $25,11-18$.

Iqbal M., Hassan A.U., Ali A., and Rizwanullah M., 2005. Residual effect of tillage and farm manure on some soil physical properties and growth of wheat (Triticum aestivum L.). Int. J. Agri. Biol., 7, 54-57.

Ji B., Zha Y., Mu X., Liu K., and Li C., 2013. Effects of tillage on soil physical properties and root growth of maize in loam and clay in central China. Plant Soil Environ., 59, 295-302.

Kadziene G., Munkholm L.J., and Mutegi J.K., 2011. Root growth conditions in the topsoil as affected by tillage intensity. Geoderma, 166, 66-73.

Kahlon M.S., Fausey N., and Lal R., 2012. Tillage effects on corn soil-plant-water continuum in alfisols of Southern Ohio. J. Agric. Sci., 4, 35-47.

Kaufmann M., Tobias S., and Schullin R., 2010. Comparison of critical limits for crop plant growth based on different indicators for the state of soil compaction. J. Plant Nutr. Soil Sci., 173, 573-583.

Kay B.D., Hajabbasi M.A., Ying J., and Tollenaar M., 2006. Optimum versus non-limiting water contents for root growth, biomass accumulation, gas exchange and the rate of development of maize (Zea mays L.). Soil Till. Res., 88, 42-54.

Kebede K. and Bekelle E., 2008. Tillage effect on soil moisture storage and wheat yield on the vertisols of north central highlands of Ethiopia. Ethiopian J. Environ. Studies Manag., 1, 49-55.

Khurshid K., Iqbal M., Arif M.S., and Nawaz A., 2006. Effect of tillage and mulch on soil physical properties and growth of maize (Zea mays L.). Int. J. Agric. Biol., 5, 593-596.

Kukal S.S. and Aggarwal G.C., 2003. Puddling depth and intensity effects in rice-wheat system on a sandy loam soil: I. Development of subsurface compaction. Soil Till. Res., 72, 1-8.

Lapen D.R., Topp G.C., Gregorich E.G., and Curnoe W.E., 2004. Least limiting water range indicators of soil quality and corn production, eastern Ontario, Canada. Soil Till. Res., 78, 151-170.

Leao T.P., Silva A.P., Macedo M.C.M., Imhoff S., and Euclides V.P.B., 2006. Least limiting water range: a potential indicator of changes in near-surface soil physical quality after the conversion of Brazilian Savanna into pasture. Soil Till. Res., 88, 279-285.

Letey J., 1985. Relationship between soil physical properties and crop production . Adv. Soil Sci. 1, 277-294 .

Liu Y., Yang S., Li S., Chen X., and Chen F., 2010. Growth and development of maize (Zea mays L.) in response to different field water management practices: resource capture and use efficiency. Agric Forest Meteorol., 150, 606-13.

Memon S.Q., Mirjat M.S., Mughal A.Q., and Amjad N., 2013. Effect of conventional and non- conventional tillage practices on maize production. Pak. J. Agric. Engg. Vet. Sci., 29, 155-63.

Mishra A.K., Aggarwal P., and Singh R., 2015. Least limited water range for two conservation agriculture cropping system in india. Soil Till. Res., 150, 43-56.

Olibone D., Olibone A.P.E., and Rosolem C.A., 2010. Least limiting water range and crop yield as affected by crop rotation and tillage. Soil Use Manag., 26, 485-493.

Ram H., Kaler D.S., Singh Y., and Kumar K., 2010. Productivity of maize-wheat system under different tillage and crop establishment practices. Soil Till. Res., 113, 48-54.

Rashidi M. and Keshavarzpour F., 2007. Effect of different tillage methods on grain yield and yield components of maize (Zea mays L.). Int. J. Agri. Biol., 2, 274-277.

Reichert J.M., Suzuki L.E.A.S., Reinert D.J., Horn R., and Hakasson I., 2009. Reference bulk density and critical degree-of-compactness for no-till crop production in subtropical highly weathered soils. Soil Till. Res., 102, 242-254.

Reynolds W.D., Elrick D.E., and Youngs E.G., 2002. Singlering and double or concentric-ring infiltrometers. In: Methods of soil analysis (Eds J.H. Dane, G.C. Topp). Soil Sci. Soc. Am. Madison, Wisconsin, USA, 821-826.

Savage M.J., Ritchie J.T., Land W.L., Dugas W.A., 1996. Lower limit of soil water available. Agron. J., 88, 651-844.

Sharma P.K. and Bhushan L., 2001. Physical characterization of a soil amended with organic residue in a rice-wheat cropping system using a single value soil physical index. Soil Till. Res., 60, 143-152. 
Shaver T.M., Peterson G.A., Ahuja L.R., Westfall D.G., Sherrod L.A., and Dunn G., 2002. Surface soil properties after twelve years of dryland no-till management. Soil Sci. Soc. Am. J., 66, 1292-1303.

Singh K.B., Jalota S.K., and Sharma B.D., 2009. Effect of continuous rice-wheat rotation on soil properties from four agro-ecosystems of Indian Punjab. Commun. Soil Sci. Plant Analysis, 40, 2945-2958.

Tormena C.A., Silva A.P., and Libardi P.L., 1999. Soil physical quality of a Brazilian Oxisol under two tillage systems using the least limiting water range approach. Soil Till. Res., 52, 223-232.

Verma S. and Sharma P.K., 2008. Long term effects of organics, fertilizers and cropping systems on soil physical productivity evaluated using a single value index (NLWR). Soil Till. Res., 98, 1-10.
Wang Y.J., Xie Z.K., Malhi S.S., Vera C.L., Zhang Y.B., and Wang J.N., 2009. Effects of rainfall harvesting and mulching technologies on water use efficiency and crop yield in the semi-arid Loess Plateau, China. Agric. Water Manag., 96, 374-382.

Wu L., Fang G., Letey J., Fergusen L., Miitchell J., Mccullongh-Saden B., and Markegard G., 2003. Soil management effects on the least limiting water range. Geoderma, 1961, 1576-1583.

Zhao Y., Pang H., Wang J., Huo L., and Li Y., 2014. Effects of straw mulch and buried straw on soil moisture and salinity in relation to sunflower growth and yield on the Loess Plateau of China. Soil Till. Res., 161, 16-25.

Zou C., Sands R., Buchan G., and Hudson I., 2000. Least limiting water range: A potential indicator of physical quality of forest soils. Austr. J. Soil Res., 38, 947-958. 